$355.02: 323.285$ (4-672EY) original scientific article

\title{
Clashing the EU security logics: complexity of EU - Hamas relations
}

\author{
Michael Schulz
}

School of Global Studies, University of Gothenburg, Gothenburg, Sweden

This article investigates the reasons behind the EU reservations and boycott towards the Palestinian resistance movement Hamas. It examines how the EU 'talked security', in terms of framing the overall Israeli-Palestinian conflict (IPC). In this context, of particular interest is the reason behind the, EU decision to label Hamas as a terrorist organization (analysed in relation to the specific security construct). With regards to the EU multilateral dimension in the IPC, it is important to find out how the EU has worked lor has been forced/pushed by external actors) to form a security governance, as well as a multilateral strategy vis-à-vis Hamas, and what references have been made towards the multilateralism. Furthermore, this article explores the policies that have been created in relation to the EU securitization of the conflict, as well as the impact it had on the EU and the Israeli-Palestinian conflict.

Key Words: security, conflict, resistance, terrorism

\section{Introduction}

This article makes an inquiry on how the EU security thinking in the field of terrorism has unfolded in relation to the Palestinian Islamic Resistance Movement, Harakat al-Muqawamah al-Islamiyya (Hamas). The article aims at linking to the field of Security Studies and International Relations by discussing how he EU has constructed its security doctrine, policies and actions in relation to Hamas who is one of the key actors of the Israeli-Palestinian. Although it, important analyses have been made concerning the EU overall securitization in relation to its neighborhood areas (the Mediterranean, the Middle East, the Caucasian and Eastern Europe) we have few who have in detailed studied the way

*Email: michael.schulz@globalstudies.gu.se

${ }^{1}$ Hamas means fire, zeal or enthusiasm. 
the EU has constructed its securitization of the Hamas organization (see for instance Pace, 2008). Why did Hamas constitute a security threat for the EU, and how has the EU built up its argumentation around the issue? Further, what EU practices have followed from the construction of Hamas as a security threat, and what have they had for impact on EU itself, as well as the overall Israeli-Palestinian conflict?

This article seeks to critically appraise the link between the EU security thinking in the field of terrorism and the security construct that the EU had built towards Hamas. The author links the analysis to the fields of Security Studies and International Relations by highlighting the genesis of the EU security thinking and by discussing how the EU actually created its security doctrine, policies and actions, in relation to one of the key actors in the Israeli-Palestinian conflict - Hamas. The European security governance is in focus of this study, and can be defined as 'intentional system of rule that involves the coordination, management and regulation of issues by multiple and separate authorities, interventions by both public and private actors, formal and informal arrangements and purposefully directed towards particular policy outcomes' (Kirchner 2007:3).

So far, important analyses have been made of the EU overall securitization concerning its neighborhood areas (the Mediterranean, the Middle East, the Caucasian and Eastern Europe). However, only few have studied in detail the way the EU has constructed its securitization towards Hamas (see Pace, 2008).

This article seeks to examine the reasons behind the evolution of the EU security thinking that constituted Hamas as security threat for the EU, analyzing also the way the EU built up its argumentation around this issue. Furthermore, this article will appraise the EU practices, as well as the impact that the construction of Hamas as a security threat had on the EU itself, and on the overall Israeli-Palestinian conflict.

\section{Terrorism as a security issue}

The EU has for a long time considered terrorism as a phenomenon that has to be given particular attention to. In the Treaty of Maastricht from 1992, the content of the third pillar for the EU notes that a closer cooperation within the police and judicial cooperation in criminal matters needs to be established. This also included combating terrorism with the Treaty underlining further that the EU undertake joint action so as to offer European citizens a high level of protection in the area of freedom, security and justice' (cited Treaty of Maastricht). 
However, with the development of the Common Security and Defense Policy (CSDP) (2003) the combat against terrorism had already increased in importance. With the European Security Strategy (ESS) that was adopted in Thessaloniki, Greece in 2003, terrorism was, along with regional conflicts, state failure and organized crime, the proliferation of weapons of mass destruction, failed states, and organized crime - defined as being among the key threats facing the EU (for more details see Kirchner and Sperling 2007:11).

One of the key questions for this analysis is: how does the EU define terrorism? First, the EU sees its whole system of democratic norms and values as something that needs to be protected. The position is that the EU is 'founded on the universal values of human dignity, liberty, equality and solidarity, respect for human rights and fundamental freedoms' (cited the Council Framework Decision of 13 June 2002 on Combating Terrorism, European Council). In this same document, an explicit definition of terrorism is made in order to combat terrorism. In the Decision we can read that 'terrorism constitutes one of the most serious violations of those principles [mentioned above]... terrorism constitutes a threat to democracy, to the free exercise of human rights and to economic and social development'(Ibid).

Further, the Decision states that any person or organization that intends to have an overarching agenda to harm or intimidate a population or government and its society is seen as a terrorist act. Article 1 in the Decision further specifies the methods that are classified as terrorist offences. They are seen as terrorist acts if committed, or if threatened to be committed and include 'attacks upon a person's life...', 'attacks upon the physical integrity of a person...', 'kidnapping or hostage taking...', causing extensive destruction to a Government or public facility...', seizure of aircraft, ships or other means of public or goods transport...', manufacture, possession, acquisition, transport, supply or use of weapons, as well as research into, and development of, biological and chemical weapons...', interfering with or disrupting the supply of water, power or any other fundamental natural resource the effect of which is to endanger human life.'(Ibid Article 1:1) By 'terrorist group' the EU means 'a structured group of more than two persons, established over a period of time and acting in concert to commit terrorist offences' (Ibid Article 2:1).

Although terrorism has been seen by the EU, since its establishment as a security issue, the emphasis of terrorism as a key security threat became increasingly securitized only after the Al-Qaida attacks on USA on 11 September 2001, when push from the US was made for the EU to join the 'coalition of willing' to combat terrorism. Several of the al-Qaida 
members of the hijacked passengers flights that crashed into the twin towers in New York and Pentagon in Washington D.C., had lived and planned the action in Europe, underlining Europe's role and un-intentional but indirect involvement.

The first al-Qaida linked attacks in Europe - specifically, the train bombings in Madrid, on 11 March 2004, as well as the 7/7 bombings in London, on 7 July 2005 accentuated, for many EU member states, the need to combat terrorism.

However, the EU failed to properly structure and to design a functional and implemental strategy, partly due to its own internal organizational inefficiencies. To a certain extent it failed due to the fact that initially the EU member states had still considered terrorism an internal matter of each member state; it was rather pushed forward, under the US and UN pressure.

The first EU reaction against terror actions came as early as 17 September 2001, much as a result of the temporary opportunity factors that occurred due to the $9 / 11$ attacks. At the Chefs de Cabinet meeting, held on 17 September 2001, the European Arrest Warrant and the Framework Decision on Terrorism, designed in 1999, now became 'accelerated and put forward as the central EU-counter measures' (cited Bossong 2008:34). However, contradictions emerged when already the next day the European Commission proposed a different and not integrated internal strategy paper that soon evolved into the first version of an Action Plan on combatting terrorism. Discussions and revisions followed for several years ending up in new revised action plans.

Even though the EU addressed terrorism as early as with the Maastricht Treaty by incorporating it in the third pillar of the document, terrorism became rapidly securitized by the EU only in the aftermath of the 11 September events. Only after 11 September 2001 did the EU begin to publish the blacklist of individuals and organizations that were suspected for committing terrorist activities placing around 35 individuals and 30 groups were on the list. The EU blacklisted them, but also ordered a freeze of the assets of the targets, and criminalized the financial support to them (for more details on this, see Cameron 2003:225).

The military wing of Hamas, the so-called Ezzedi Al-Qassam brigades, was among the organizations that were blacklisted already in 2001, under the European Council decision. By 2003, the entire Hamas organization (including the political and social wings of the organization) was blacklisted. In the EC decision that was published in the Official Journal of the European Union (EC 2003/646), Hamas, along with six other Palestinian 
groups $^{2}$, as well as one Israeli group ${ }^{3}$ and other non-IPC related groups were labeled as terrorist.

Having in mind the EU definition on terrorism the key question that arises is why was Hamas banned? Noteworthy here would be to examine how the $9 / 11$ events interplayed with the way the EU perceived the role of Hamas, and more concretely, how the 9/11 events interplayed with the decision to ban Hamas. The second critical question would relate to way the ban had been implemented and the impact it had on the EU as actor to the IPC, as well as vis-à-vis Hamas.

\section{Evolution of the case: EU, IPC and Hamas}

Starting point in this section is to evaluate the causes behind the way the EU has positioned towards Hamas. Also, it will be shown, when and how the EU perceived Hamas as a security concern. We need to address the three key areas in which the EU has expressed its positions concerning the IPC. Firstly, it is about how the EU frames the conflict itself and the issues related to it - including the role that the key actors should have in a future potential peace process, which should lead to a just and durable settlement. Secondly, the way the EU perceives its role as a normative power in terms of expressing democratic freedom, human rights and freedom of expression has an impact on how the EU acts vis-àvis Hamas. Thirdly, the role that the EU has taken upon itself in the 'war on terror' paradigm has also an impact on its stance towards Hamas.

All the three areas contribute to understanding how the EU formulated and expressed the security issue of terrorism - and the reasons of why Hamas in particular, is considered to be of security concern for the EU.

\section{Previous EU role in the IPC}

Even before Hamas was established (1987/88) and before the EU was founded (1992), we had witnessed a slow and gradual process towards an increasingly coherent European position vis-à-vis the IPC. For years, the European states took no-coordinated

2 These are the Abu Nidal Organization, Al-Aqsa Marty's Brigade, Palestine Liberation Front, Palestinian Islamic Jihad, Popular Front for Liberation of Palestine (PFLP), Popular Front for Liberation of Palestine-General Command (PFLP-GC).

${ }^{3}$ Kahane Chai (Kach) 
actions in the Middle East. Only after the 1960s did a more harmonized position begin to evolve.

Though, some of the historical differences within Europe continue to form part of the contemporary internal discussions within the EU. For instance, France was more critical towards Israel compared with West Germany that felt strong commitments to Israel. Due to the historical actions against the Jews in the Holocaust during WWII, West Germany, felt that it wanted to contribute to the establishment of the Jewish state. In fact, West Germany had paid reparation for the Holocaust, contributing substantially for the built up of a modern Israeli welfare state during the 1950s (for more details, see Schulz 1996). Even today, Germany is seen by Israel as the most reliable ally within the EU. Concurrently, already in 1974the Swedish Prime Minister met as the first Western leader, the PLO leader Yassir Arafat, (Rabie 1992) One year later, in 1975, France became the first Western country to allow the opening of a Palestine Liberation Organization (PLO) office (Dieckhoff 2005). In 1988 Sweden, again became instrumental - this time, in bringing the USA closer to the PLO which partly contributed to open the road to the first peace conference held in Madrid 1991, marking the beginning of the so-called Oslo process directed by Norway.

Despite the different positions European states had towards the IPC parties, there was a unison statement that was given by all member states to the European Economic Community (EEC) with the 1980 Venice Declaration, underlining:

'..the right to existence and to security of all States in the region, including Israel, and justice for all the peoples, which implies the recognition of the legitimate rights of the Palestinian people...A just solution must finally be found to the Palestinian problem, which is not simply one of refugees. The Palestinian people, which is conscious of existing as such, must be placed in a position, by an appropriate process defined within the framework of the comprehensive peace settlement, to exercise fully its right to self-determination'. (Venice Declaration, 1980. For more details, see Dieckhoff, 2005:53).

The Venice Declaration had thereby already paved the way for the so-called twostate solution, implying a Palestinian State to be established in the West Bank and the Gaza Strip occupied in 1967 by Israel. This principle has become a firm position, and particularly the Palestinians' right to self-determination has been continuously emphasized. This is why, when Israel and the Palestine Liberation Organization (PLO) signed the Declaration of Principles in 1993, which resulted into the establishment of a Palestinian 
Authority (PA), led by the PLO chairperson Yassir Arafat, and also the Head of the Fatah movement within the PLO, the EU immediately supported this agreement.

The EU stressed further the initial Venice ideas with the important European Council meeting in Berlin 1999 when the EU took an explicit declaration, stating that 'the European Union reaffirms the continuing and unqualified Palestinian right to selfdetermination including the option of a state and looks forward to the early fulfilment of this right (cited from Berlin EU Council 1999).' On the one hand, the EU thus underlined the two-state model, but also declared that the parties should reach a negotiated agreement, thereby hinting to the option that if the Palestinians would accept solely self-determination and not statehood, the EU would not prevent the establishment of a Palestinian State.. However, it could also be seen as a position in which Israel feels that the EU would not stand in its way in case Israel decides to push against the establishment of a Palestinian state. The EU position in 'support for a negotiated settlement in the Middle East (cited from Berlin EU Council 1999)' underlines further its strong disagreement to the usage of violent means against the Israeli occupation, or Israeli violent attacks on Palestinian militants. This position must be mirrored to the Europeans horrifying historical experience of WWI and WWII when diplomatic efforts failed and threw mankind into disastrous wars and violence. Hence, diplomacy and negotiations is a normative principle for how EU sees that conflict parties should resolve their differences.

The EU has increasingly become involved in the IPC since the beginning of the peace process in the 1990 s. Despite many claims that the EU plays a marginal role, compared with the USA, the EU is by far the most important economic player for both, Israel and the Palestinian self-rule areas in the West Bank and the Gaza Strip, i.e. the Palestinian Authority. Despite the close political linkages with the USA, Israel's biggest trade partner is the EU. The weak Palestinian economy has developed a dependency relation with the EU. The EU had initiated the Barcelona process in 1995 and that was aimed to support and push the peace process between Israel and the Palestinians forward, but also aiming to develop closer relations with the Mediterranean neighbors (Tocci 2005, Gomez 2003). With the Barcelona framework it followed up with the European Neighborhood Policy (ENP) in early 2002, in which the EU stated the need to develop friendly associated neighbors surrounding EU's new members. The EU paid more then half of the money that was invested in the 0slo peace process in 1991-2000. 


\section{Secururity}

\section{The EU positions vis-à-vis the IPC}

However, we need to scrutinize the key documents reflecting the EU position and statements about the IPC, and in particular with reference to the different parties, including Hamas. Although the Venice Declaration can be seen as a first step towards the form of a solution that has now reached global consensus, we still need to address the various steps taken within the EU itself vis-à-vis the conflict parties in relation to the solution. How did the EU formulate its solution and how did it perceive the responsibilities in relation to the conflict parties themselves? Further, when did Hamas occur as a security threat in the EU documents, and how was this threat described? If we first go through the key documents related to how the EU perceives the way forward in the IPC, one can analyses several key documents presented primarily by the European Council, as well as the Higher Representative of the EU.

The EEC position that came with the Venice declaration in 1980 also gave legitimate right to the PLO as the sole representative of the Palestinian people. Hence, the EEC, and later the EU had thereby made a conflict analysis in which they framed the previous Arab-Israeli conflict as secondary to the overarching IPC. The Palestinians, along with Israel were therefore seen as the core parties, and only when they find an (negotiated) agreement, could peace occur. The EU made it explicit that the key issues to be addressed in peaceful talks were the illegal Israeli settlements in the West Bank and the Gaza Strip, Jerusalem, Palestinian refugees' right of return, as well as the future Palestinians international boundaries. Israel was furious over the decision, and in 1985, the person who himself was later given the Nobel Peace prize for signing in 1993 the Declaration of Principles with the PLO, Shimon Peres, claimed at the European Socialists meeting in Vienna that this was wrongdoing and requested the EU 'to cease closing their eyes...and to refrain from an attitude of forgiveness' towards the PLO (quoted in Miller 2006: 643). Supporters of the statement saw the EU position to place the PLO as the other key actor to the conflict next to Israel as forerunner action to the present mainstream solution - the two-state solution. However, when Hamas became a challenger to the PLO, as a religious Palestinian national movement and an alternative to the secular PLO nationalism (see Abu Amr 1994, Lindholm Schulz 1996, 1999) the EU could not initially realize and even less, recognize this challenge against the secular Palestinian nationalism of the PLO.

The entrance of Hamas on the political scene came already during the first intifada in 1987-1993, however, not until its first suicide mission in 1993 in the West Bank, and even 
more after the April 1994 attack inside Israel, did the EU take real notice of Hamas as a political challenger vis-à-vis PLO. At this time, the EU mainly perceived Hamas as a spoiler to the peace process that made it difficult for President Arafat (formally the chairperson) of the PA to achieve success at the negotiation table with Israel. Equally, Israel was given full support, and de facto acceptance of Israel's measures to prevent further Hamas attacks on Israeli civilians. EU's own conflict analysis of the IPC gave itself the role of being the party that primarily should provide development assistance to the PA, and ensure that the PA would transform into a democratic forthcoming Palestinian State when the interim period, according to the Oslo Accord, should be completed in September 1999. When the 0slo interim period came to its end, the EU Berlin Declaration came in 1999 to support again that the two-state solution should be implemented, thereby giving support to the Palestinians, and in particular the Arafat led PA. With the outbreak of the Second Palestinian uprising, the so-called al-Aqsa intifada, in September 2000 the EU ended up in a new situation in which it also had to question some of its key position. Nevertheless, during the entire period and up to the Hamas election victory, the EU came to support the PLO/PA and even supported Arafat until his death, and after that he was imprisoned by Israel in his own office in 2002, the Muqatha, in Ramallah. The EU thereby opposed Israeli and American positions that preferred to see Arafat as the key problem of the situation. In contrast to the EU, Israel and the US saw Arafat as the cause to the stalled peace process, not least due to Arafat's lack of willingness to prevent Hamas and other terror organizations' attacks on Israel. The EU rather saw him as the key to the solution.

\section{EU security governance and Hamas}

Given the above analyzed key documents one asks what type of security governance followed from the EU reasoning and construction of the conflict

The overarching understanding of how the EU security governance strategies are formed should be divided along two dimensions.

Firstly, it is important to understand the way the EU has framed the IPC, since the contextualization of the conflict, de facto, generates the type of practices that would follow. The way the conflict is described, in terms of historical narratives and root causes; the key actors the EU points out; the way it perceives the key issues, and finally, the preferred solution for the EU - all these aspects impact the security governance formulation. Secondly, the influence from the various single member states' individual (different) 
construct of the IPC, matters immensely for how decisions are taken-for instance, in the European Council. Therefore, a single member state's involvement on the ground within the conflict context does not necessarily imply it is coordinated with the EU stance and activities. As will be shown further, the security governance strategies are impacted from the 'Brussels' security governance discourse and the EU day-to-day security governance on the ground.

The overarching approach taken by the EU is to emphasize that the parties should refrain from using violent means, but solve their differences in diplomatic talks and negotiations. The underlying logic is linked to the normative perception that with a democratic take you need to find compromised solutions. If not instantly reached, you just continue without returning to the usage of violent strategies. Also, the EU perception is that when parties negotiate and have dialogue, they do not fight, and thereby increase the likelihood to narrow, as well as overcome the gaps between the conflict parties. The EU sees any party that does not follow the diplomatic track as a spoiler to the peace process. With the self-perception of being a 'force of good' that promotes human rights, democracy and peaceful means in solving conflicts, the EU will, at least on the rhetorical level, condemn parties to the conflict if this is not followed or implemented.

However, the construction of being a normative power on a rhetoric level has shown to be less consistent with the practices vis-à-vis the actors to the conflict, as will be discussed below. For now, we can see that the EU has condemned the parties when, for example, Israel continued to construct settlements in the West Bank, or when suicide actions against Israeli civilians by Hamas took place. These condemnations rest upon the EU position that a two-state solution implies the establishment of a Palestinian state in the West Bank and the Caza Strip, with East Jerusalem as its capital. Hence, any Israeli settlement built in these areas, or usage of violent means by any party, or the denial of Palestinian refugees rights is seen by the EU not solely as a contradiction to EU's own conflict analysis of the IPC, but also as a violation of the international law.

Analysis of the Oslo process between 1993-2000 until the outbreak of the al-Aqsa intifada shows that the EU was also willing to contribute to strengthening the PA and the former President Yassir Arafat's regime, contrasted with the opposition constituted primarily by the Islamists, i.e. Hamas and Islamic Jihad. Hence, despite its own normative position that it is essential to talk and hold relations with all parties to a conflict, the EU relatively early on sided solely with the Arafat led PA and framed the opposition as nondemocratic and as spoilers. 
The EU saw the PLO/PA as the key party next to Israel and the actor that could bring a negotiated peace in accordance with the two-state solution. Hence, in line with the US position, the EU has never accepted the Palestinian view that violent resistance against Israeli occupation is legitimate according to international law. Non-violence is in line with its principles to solve conflict via negotiations, and is a corner stone of the normative basic position of the EU. A further example of the negotiation track is when the EU High Representative Catherine Ashton announced, after the killing of four Israelis in Hebron in September 2010, that '[it] is very important that all relevant parties avoid provocative actions which could undermine the success of the talks' (Brussels, 2 September 2010, A 171/10). This normative position has led academics to label the EU as a normative power (Manner 2002), civilian power (Bull 1982), or 'force for good' (Barbé and Jahnsson-Nogués 2008). The logic of this normative construct has also its consequences for how the EU acts in relation to the actors of the conflict. Furthermore, the EU identifies its role as a partner primarily with the USA. The EU sees the USA as a key partner in the Middle East peace process.

Its entry and direct involvement in the peace process, following the aftermath of the 1993 Declaration of Principles between Israel and the PLO, made the EU become the major economic partner for the Palestinians. Furthermore, the EU saw its role in ensuring that a Palestinian counterpart did exist. Hence, the economic and political backing of the PLO/PA was a crucial step in this direction. Initially, the division of labor between the EU and the US was that the EU took upon itself to build and consolidate the PA, while the USA was focusing on the bilateral talks between Israelis and Palestinians. However, during the last decade the EU has become increasingly involved in mediation and hardcore security issues. Hence, the EU is contradicting its normative position, but argues that it has to be also involved in hard-core security issues in order to increase its role and influence. However, the EU security involvement is still within the field of security sector reform, in which Palestinian police forces are trained in a 'rule of law' spirit, and seen as part of its civilian missions. Though, as will be described further, the developments on the ground, in the conflict context, affected heavily the implementation of the EU security governance, as well.

The EU security governance strategy and its impact could be divided into three overarching phases: the period starting from September 1993-August 2000; the al-Aqsa intifada period from September 2000 until the Hamas election victory on 25 January 2006; and the post-election period until present time. 


\section{Securiaty}

\section{September 1993 until September 2000}

In the Oslo peace process the EU emphasized the need to provide the newly established PA with economic support, but also to build a democratic PA, as well as rule of law based structure with respect for human rights. However, after the assassination of the Israeli Prime Minister Yitzak Rabin in November 1995, and following the escalation of Israel and Hamas confrontations, with several Hamas suicide attacks during February and March, killing over 40 Israelis and injuring over 200 (Miller 2006: 644), and the election victory of the previous opposition leader from the Likud, now Prime Minister Binyamin Netanyahu, the peace process if not stalled, at least dramatically slowed its pace. Prime Minister Binyamin Netanyahu had been the principal voice in criticizing the entire 0slo formula.

The EU that had invested not solely money into establishing a PA, but also managed to receive a key role in the peace process, felt an urge to underline the importance of a sustained peace process. Hamas had been perceived as a spoiler during the entire 0slo process, and the EU felt the need to side with the Arafat led PA. The idea was to provide support for Arafat and that he should prevent Hamas from making their attacks on Israel. Hence, this EU reaction was in response to a harder position from the new Israeli government against the $\mathrm{PA}$, but also a clear signal to Hamas that they were perceived as a destructive force of the Palestinians aimed at achieving statehood and peace with Israel. As a response to the Netanyahu election victory, in June 1996 the European Council meeting in Florence stressed that the 0slo process was a fundamental interest of the EU. Hence, most resources went to uncritically support the PA, despite internal critical EU voices, which in practice meant to strengthen the Arafat controlled security forces that were to be used to clamp down on Hamas and other terror organizations. Also, the US with the help of CIA, organized ways of strengthening Arafat's capacity to prevent Hamas and similar organizations to conduct suicide attacks against Israeli civilians. This was also in line with the perspective to provide tools that could make Netanyahu claim that he had achieved what he promised the Israeli electorate, namely personal security. The EU hope was that this would strengthen Israeli's willingness to compromise. However, among the Palestinians frustrations and disappointments increased with the Israeli government's actions and the lack of US and above all EU pressure on the Israeli leadership.

When Prime Minister Barak had won the elections in 1999 hopes increased again for a settled solution towards the establishment of a Palestinian state. The EU was seen as a passive voice that merely sided with the US position. 


\section{Securiaty}

\section{September 2000 to election victory of Hamas in 2006}

During the entire Oslo-process, the EU consequently urged and requested the PA to be willing on arresting Hamas and Islamic Jihad activists that used violent means (in particular the suicide attacks against civilians). With the outbreak of the al-Aqsa intifada this request was intensified. However, the al-Aqsa intifada was not solely an uprising against the Israeli occupation, and the frustrations that followed with the failed Camp David II negotiations. The uprising was also a clear signal against Arafat and the PA of not being able to succeed at the negotiation table with Israel, and also not to provide the social welfare and services that the PA should take care of. Hence, the uprising was also a protest against the corrupt Arafat regime, and particularly the Hamas leadership criticized Arafat and his PA (for more detail see Lindholm Schulz 2002).

The violent escalation during the first half of 2002, including several suicide attacks against Israeli civilians, as well as Israel's re-invasion of the PA controlled area A in the West Bank, further weakened Arafat's position. Already before this escalation, on 15 December 2001, in a press release of the European Council, the EU expressed that the 'only basis for peace is UN Resolutions 242 and 338...', implying that the Palestinians' right for self-determination must be taken care of. Moreover, the EU again underlined 'Israel's inalienable right to live in peace and security...', and simultaneously, the purpose of 'establishment of a viable independent and democratic Palestinian state and an end to the occupation...' (cited European Council Declaration of 15 December 2001). Thereafter follows a reminder to the Palestinian Authority to take actions against the Islamists by 'the dismantling of Hamas' and Islamic Jihad's terrorist networks...' (Ibid).

Israel, and the Sharon cabinet, perceived Arafat as the sole problem having failed to take serious actions against Hamas and other Palestinian terror organizations. The EU also expressed its concerns for Arafat's incapability to clamp down on these groups. However, when Israel isolated Arafat in the Muqata the EU decided to side with him. When Israel and the PA, backed and supported by the Quartet, (constituted of the UN, the US, the EU, and Russia) adopted the Roadmap for peace on 30 April 2003, it only followed the EU's previous statement on how the IPC should be ended. A requirement to cease all fighting was particularly expressed towards Hamas.

This position was further emphasized with the next European Council meeting in June 2003 in Thessaloniki Article 83 of the revised document from the meeting states the following: 
'The Union demands that Hamas and other groups declare a ceasefire immediately and halt all terrorist activity and recalls that the Council is urgently examining the case for wider action against Hamas fund raising. It is essential that all concerned, in particular the countries of the region, condemn terrorism and assist in efforts to eradicate it.' (cited European Council, Brussels, 10ctober 2003)

When Israel denied access to the EU representatives to visit Arafat in the spring of 2002, the EU even expressed considerations to reconsider its trade relations with Israel. Hence, the EU took a stand against its allies - Israel and the US, on how to approach Arafat and the PA. It is within this light one also has to see that the internal EU discussion on how to approach Hamas was linked to how the EU best could tackle the too firm Israeli and US position towards Arafat. It became increasingly difficult, particularly for smaller states to resist the continuous pressure from primarily the UK, Germany and the Netherlands, that were closer to the US positions on how to have a tougher stand towards Hamas. Hence, as has been argued by Cameron (2003), it became hard to say 'no' and stand against blacklisting Hamas, since it became more important to give legitimacy to the PA and Arafat in a situation when the US began to question Arafat. Hence, a ban against the PA opposition simultaneously could therefore be argued to support the PA and Arafat as the sole legitimate representative of the Palestinians. Furthermore, since now Arafat and the PLO/PA, as well as Israel, had accepted the Roadmap, further arguments came claiming that a ban on Hamas would weaken and prevent Hamas to work against the implementation of the Roadmap. Therefore, it is no coincidence that the blacklisting came in the autumn of 2003 after years of discussion on how to approach the Islamists. Hence, again the EU saw the PLO/PA as the legitimate representative of the Palestinians, and the Islamist as spoilers, and not as a real opposition force in Palestinian society.

Despite that, heavy criticism came from inside PLO and Fatah itself about Arafat's way of running the chronic corruption situation, and which came to a close bankruptcy (Miller 2006: 648).

Following Arafat's death in November 2004, Hamas decided to participate in the municipality elections that were held in four rounds - December 2004, January 2005, May 2005, September - December 2005. This marked the beginning of a new situation for Hamas leverage that was further accentuated with the national election victory Hamas held in January 2006. 
Hamas did not win all municipality elections, but it did well and this outcome put the EU in a new difficult position, since it could no longer place Hamas only as a spoiler of the conflict. Due to its popular support, as well as acceptance to take part in democratic elections, Hamas proved to be not solely a resistance movement, but also an actor capable to take part in political decision-making. Furthermore, by participating in the elections Hamas accepted one pillar of the 0slo process, and could thereby be seen as a party to involve in future talks.

In June 2003 Hamas declared a ceasefire, an Islamic hudna, implying a long-term ceasefire between Muslims and non-Muslims, which was also in line with the EU requests. However, the ceasefire was broken after merely six weeks. Israel then continued its extrajudicial assassinations of Hamas leaders and along with militant leaders now came to include also the political leaders of Hamas as legitimate targets in this strategy. The EU, as well as the US, vocally protested these actions but did not really pressure Israel to stop.

In 2005, a temporary ceasefire, a tahdiah (calm period) was announced by Hamas and it coincided with the Palestinian municipality elections (Gunning 2007: 222). This also coincided with Israel's unilateral withdrawal from the Gaza Strip. Again the EU chose to give support and credit to the Israeli government led by Ariel Sharon for its readiness to sacrifice territory in exchange for peace, rather than giving credit to Hamas for announcing a ceasefire, and in spite of Palestinian public pressure to fight back against Israel.

This ceasefire was held until June 2006 when tensions arose also between the Hamas government and Fatah that was supported by Israel and the US seeking to undermine Hamas government. The EU had internally increasing discussion on how to approach Hamas, and was considering taking Hamas out of the blacklist. However, no consensus was reached. The UK Prime Minister Tony Blair had since 2003 and 2004 pushed for a crackdown on Hamas and was the key player within the EU to prevent the establishment of a more official EU line towards Hamas. In June 2007 he accepted the role as the Quartet's representative. Hamas who considered his appointment as deride instantly criticized Blair as being clearly biased.

\section{From 2006 to contemporary time}

The national election victory of Hamas forced the EU to take a move in which it still could argue that Hamas was democratically elected in a free and fair elections, and simultaneously find a way out for risking to be accused for financing a terrorist 
organization. Hence, jointly with the other Quartet members, the EU raised three principles that Hamas should follow if it wished to have relations with the Quartet members. These were the following ones: 1. recognition of Israel's existence and right of existence, 2. renounce the use of violence in its struggle to end Israeli occupation, and 3. acceptance of the agreements that the PLO had signed with Israel (the agreements within the frame of the Oslo process) (see 0'Donell 2008). At a closer look, Hamas had de facto since then already held the ceasefire; since 2005, it had already shown capability to refrain from use of violence against Israel, and it could accept to have an open dialogue.

A year later, the tensions between Fatah and Hamas escalated and Saudi Arabia mediated this internal strains resulting in the Mecca Agreement of February 2007. Hamas had then agreed to form a unity government with Fatah and expressed its willingness to respect the previously signed agreements between Israel and the PLO. In relation to Israel, Hamas leader Khaled Meshal had already stated before the Mecca meeting the following proposition:

'We in Hamas are with the general Palestinian and Arab position and we are with the consensus of the necessity of establishing a Palestinian state on the 4 June borders, including (East) Jerusalem, the right of return and the withdrawal of Israel to these borders.' (cited Kahled Meshal 10 January 20074).

However, Meshal also claimed: '...that doesn't mean that we recognize Israel. But we are prepared to make a long term truce with Israel. Accepting the status of Israel without recognizing it.' (cited Meshal 12 December $2006^{5}$ )

In other words, Hamas came forward nearly on all aspects that the Quartet had demanded from Hamas. Still, the fact that Hamas was only ready to respect and honor the previous agreements that PLO had signed with Israel was in the eyes of the EU too limited, and different than actually accepting them. For Israel, the US and the EU it was of outmost importance that Hamas also recognized Israel's right to exist. The mere fact that Israel exists was not enough.

Paradoxically, Hamas had even before the election victory accepted the idea to join the PLO, and if Fatah had allowed Hamas to become a member, it would have de facto been an implicit acceptance of the previous agreements between PLO and Israel. The PLO had

${ }^{4}$ http://www.reuters.com/article/2007/01/10/us-palestinians-meshaal-text-idUSL1046412720070110 (accesses 1 August 2014)

${ }^{5}$ http://www.antiwar.com/orig/rupp.php?articleid=10195 (accessed 1 August 2014) 
already recognized Israel's right to exist via the Oslo Accord in 1993. In addition, it is difficult to neglect Hamas' increased awareness the need to adjust their position in relation to Fatah. In Article 9 of the National Unity Platform that Hamas negotiated with Fatah and other political fractions in 2006, Hamas committed itself in that: 'the government will deal with the signed agreements [between the PLO/PA and Israel] with high responsibility and in accordance without compromising its immutable prerogatives' (cited Hroub 2006, p. 17). Furthermore, in Article 10 they state that: "the government will deal with the international resolutions [on the Palestine issue] with national responsibility and in accordance with protecting the immutable rights of our [Palestinian] people' (Ibid.)

For Israel, in particular, but also the US and the EU this was not enough. And still, if, compared with the Hamas Charter of 1988 the National Unity Platform suggests that Hamas has made a major shift. Hamas position was made explicit in the sense that it would respect the basis of the 0slo agreements, but only if the Palestinian rights are fulfilled. Hamas critical voices claim that these rights could include the establishment of an Islamic Palestinian state in the whole of Palestine, thereby implying the destruction of Israel. However, a more detailed analysis shows that this should be seen as an indirect acceptance of a two-state solution, at least as a long-term temporary solution. Hence, Hamas is underlining this position, also due to its need to be seen as an equal partner with Israel.

Within the EU, these shifts in Hamas positions on those key issues did not pass unnoticed. Even more, they increased the internal debate within the Union on lifting Hamas away from the blacklist. Moreover, a debate on the need to break the isolation that began in the spring of 2006 and to open dialogue with the movement intensified. (or: Moreover, voices within the Union intensified in favor of breaking the isolation that began in the spring of 2006 and opening the dialogue with the Hamas movement.) The demands by the Foreign Affairs Committee of the UK House of Commons and the Italian government requesting an end to the boycott against Hamas are only some of the examples illustrating the individual actions undertaken by some of the EU member-states in this direction. Sweden even granted an entry visa for a Hamas government minister in 2006; the European Parliament publically called for an end of the boycott; several EU officials in the European Commission and several member states privately confessed the need to approach and engage with Hamas. Even "hardliners" such as Germany managed to pressure Israel to accept a ceasefire with Hamas in the spring of 2008 (0'Donell 2008: 18). Germany was also involved, jointly with Egypt in mediations with Hamas and Israel. The aim of these mediations was to find a formula for a possible prisoner exchange of a lesser number out of 
the 11,000 Palestinian prisoners in Israeli custody in exchange for the release of the Hamas kidnapped Israeli soldier Gilad Shalit.

However, the dilemma for those member states who want to lift the blacklisting of Hamas is that the EU requires a unanimous decision in order to take Hamas down from the blacklist. With every backlash, such as the Gaza war in December 2008-January 2009 between Israel and Hamas, or after the Israeli raid on the Gaza flotilla in May 2010, or the most recent armed conflict in July-August 2014 between Hamas and Israel, the discussion intensifies, but it also makes it more difficult for EU member stated to reach a consensus within the EU.

Without clear consensus among its member states, the EU has ended up siding with the Quartet, only or, verbally criticizing Israel but without any real threat to break trade or diplomatic relations with Israel, or even less - possibility to open dialogue with Hamas.

\section{Conclusions}

In reaching conclusions about the EU securitization of Hamas as an actor to the IPC conflict several things must be borne in mind. First, the EU has a clear vision of how the overall IPC should be solved. The EC had already placed the two-state solution on the table before the EU was established in 1992. The key actors of the IPC were according to the EU conflict analysis Israel and the Palestinians. The EU strong pro-PLO position in the sense of perceiving them as the sole representatives of the Palestinian people, made it difficult for the EU to recognize the challenge that Hamas constituted given its increased popular support, as compared to the PLO dominated PA that had been established as a result of the entire 0slo process between Israelis and Palestinians.

Second, key EU documents identify on a more general level that terrorism is a security concern. However, it is only in relation to the aftermath of the $9 / 11$ events that Hamas became a direct security concern for the EU and was consequently blacklisted in 2003. The blacklisting of Hamas took place despite the fact that the al-Aqsa intifada included all political fractions in its struggle against the Israeli occupation. Several other groups would have also qualified to be blacklisted by the EU. If the EU would have strictly followed its own definition on what terrorism is, the Israeli target killings of Hamas members would have qualified Israel for blacklisting as well. However, this must be seen in relation to the fact that the EU was stuck with its earlier way of making its conflict analysis 
of the IPC, its prestige and investment in emphasizing the need to support the PLO and the newly established PA (not least in relation to the US), as well as the impact of US and UN pressure on the EU to act after the $9 / 11$ events. At the same time, one could argue that the normative aspects of the EU, i.e. that conflict parties should talk and negotiate and not use violence - as one pillar for solving conflicts, create a logical argumentation in relation to Hamas and its violent means, such as suicide attacks on Israeli civilians.

However, the increasing stalemate of the Oslo process, the increased corruption tendencies of the PA and Arafat's dominant and non-democratic leader style, as well as the armed resistance of the Hamas movement against Israel, showed how trapped the EU was in its own discourse of speaking security, both on a general level about the IPC and more specifically about Hamas. This inability created further challenges for the EU when Hamas won the national elections. By constantly arguing for the need to participate in political dialogues, in a democratic structure, one could have expected that when Hamas actually decided to accept one of the Oslo pillars, to participate in political competition of how the PA should be run, the EU should change its relation vis-à-vis Hamas. By siding with Israel and the US and isolating and boycotting Hamas, the clear impact on the Palestinian public, as well as Hamas itself, was that the EU works with double standards.

This has also led to an increased internal debate within the EU itself, and at this point it remains unclear in what direction the EU will go in the future. However, one can assume that the future EU course will be mostly decided by the IPC actors, themselves, i.e. the conflict developments per se will impact the potential shifts in the EU course. Given the current on-going differences within the EU on the IPC context and its actors, there is little likelihood that a major internal shift would occur in short term perspective, in which a consensus would be reached on how to approach Hamas in a new way, in which the movement would not be seen solely as a terrorist organization, but also as a key player, similar to how the PLO was seen before the Oslo process, in the beginning of the 1990s.

The theoretical implications of these findings indicate that the EU security governance policies are shaped by the way it analyzes its security concerns and the way it 'speaks security'. However, due to its inabilities, not least due to the conflicting positions among the EU members themselves, the capacity to shift its security governance policies either come too late or do not come at all. Also, the EU impact in the conflict zone itself creates several warning signals, but seemingly do not reach Brussels in time, or are not convincingly enough for the located EU officials to signal to Brussels on what needs to be changed. 
This implies that we have one type of, Brussels security governance, with its own life and linked to its previous security discourses and multilateral understandings, and another type of EU-IPC security governance, on the ground, with a different logic, understanding and functioning. Theoretically, the study findings also go in line with previous studies, such as Pace (2007) who also argues that there are gaps between the rhetoric level of the EU and what happens on the ground. Also, in line with the dilemmas the EU faces with its perception of being a 'force of good' (Barbé and Johansson-Nogués 2008), and acting contradictory in the field in relation to its normative overarching principles. This creates a view of an unclear EU position at best, and double standards in the eyes of the conflict parties (Berg \& Garthon 2009), making it utterly difficult for the EU to become a trustworthy mediator in the conflict. The relationship between these two security governance logics and their impact seem to be of importance and hence should be of further empirical research interest.

\section{References}

\section{Primary sources used}

1. European Union. 1992. Treaty of Maastricht on European Union, Maastricht [online]. Available from: http://eur-lex.europa.eu/legalcontent/EN/TXT/PDF/?uri=0J:C:1992:191:FULL\&from=EN [Accessed 20 July 2014].

2. European Council. 1999. Presidency Conclusions. Berlin European Council, Berlin [online]. Available from:

http://www.consilium.europa.eu/uedocs/cms_data/docs/pressdata/en/ec/acfb2.ht ml [Accessed 20 July 2014].

3. European Council. 2002. Declaration by the EU on the Middle East, Seville [online]. Available from:

http://domino.un.org/UNISPAL.nsf/eed216406b50bf6485256ce10072f637/592c1c6 421404b2985256c7500575367?0penDocument [Accessed 20 July 2014].

4. European Community. 1980. Venice Declaration [online]. Available from: http://eeas.europa.eu/mepp/docs/venice_declaration_1980_en.pdf [Accessed 26 July 2014] 


\section{Securitity}

\section{Bibliography}

1. Kirchner, E. and Sperling, J. 2007. EU security governance. Manchester: Manchester University Press.

2. House of Lords. 2007. The EU and the Middle East peace process: twenty-sixth report of session 2006-07 of the Great Britain Parliament European Union Committee. London: House of Lords.

3. Abadi, J. 2001. Sweden's policy toward Israel: constraints and adjustments. Middle Eastern studies, 37 (2), 23-49.

4. Abu-Amr, Z. 1994. Islamic fundamentalism in the West Bank and Gaza: Muslim Brotherhood and Islamic Jihad. Bloomington and Indianapolis: Indiana University Press.

5. Aoun, E. 2003, European foreign policy and the Arab-Israeli dispute: Much Adi About Nothing? European Foreign Affairs Review 8, 289-312.

6. Barbé, E. and Johansson-Nogués, E. 2008. The EU as a modest 'force for good': the European Neighborhood Policy. International Affairs, 84, 1 (2208) 81-96.

7. Berg, C. and Gahrton, P. 2009. 'Civilization' of the EU. A way for the EU to do more for world peace? Stockholm: Cogito

8. Bull, H. 1982. Civilian power Europe: a contradiction in terms? Journal of Common Market Studies, 12 (2), 149 - 164.

9. Cameron, I. 2003. European Union anti-terrorist blacklisting. Human Rights Law Review, 3 (2), 225-256.

10. Del Sarto, R. A. 2007. Wording and meaning(s): EU-political cooperation according to the ENP Action Plan. Mediterranean Politics, 12 (1), 59-75.

11. Dieckhoff, A. 2005. The European Union and the Israeli-Palestinian conflict. Journal Inroads, 16, 52-62.

12. Gomez, R. 2003. Negotiating the Euro-Mediterranean partnership. Strategic action in EU foreign policy? Aldershot: Ashgate Publishing Limited.

13. Gunning, J. 2008. Hamas in politics: democracy, religion and violence. Colombia University Press.

14. Hollis, R. 2004. The Israeli-Palestinian road block: can Europeans make a difference? International Affairs, 2 (2004), 191-201.

15. Hroub, K. 2006. A 'new Hamas' through its new documents. Journal of Palestine Studies, 35 (4), Summer, 2006.

16. Kirchner, E. J. \& Sperling, J, 2007, EU Security Governance, Manchester: Manchester University Press. 
17. Lindholm Schulz, H. 1996. Between revolution and statehood: reconstruction of Palestinian nationalisms. Department of Peace and Development Research: Göteborg University, Doctoral Dissertation.

18. Lindholm Schulz, H. 1999. The reconstruction of Palestinian nationalisms: between revolution and statehood, Manchester University Press.

19. Lindholm Schulz, H. 2002. The 'al-Aqsa Intifada' as a result of politics of transition. Arab Studies Quarterly (ASQ), 24 (4, Fall), 21-46.

20. Manner, I. 2002. Normative power Europe: a contradiction in terms? Journal of Common Market Studies, 40 (2), 235-58.

21. Miller, R. 2006. Troubled neighbors: the EU and Israel. Israel Affairs, 12 (4), October 2006, 642-664.

22. Mohamed, R. 1992. The U.S. - PLO dialogue: the Swedish connection. Journal of Palestine Studies, 21 (4), Summer, 1992, 54-66.

23. O'Donell, C. M. 2008. The EU, Israel and Hamas. Working Paper. Centre for European Reform, April 2008.

24. Pace, M. 2007. The construction of EU normative power. Journal of Common Market Studies, 45 (5), 1041-1064.

25. Tavares, R. and Schulz, M. 2006. The intervention of regional organizations in peace building. In P. De Lombaerde, ed. Indicators of Regional Integration. London: Routledge.

26. Tamimi, A. 2007. Hamas unwritten chapters. London: Hurst \& Co. Ltd.

27. Tocci, N. 2007. The EU and conflict resolution: promoting peace in the backyard. London and New York: Routledge.

28. Tocci, N. 2005. Conflict resolution in the Neighborhood: Comparing EU involvement in Turkey's Kurdish question and in the Israeli-Palestinian conflict. Mediterranean Politics, 10 (2), 25-146.

\section{Internet sources}

1. EU Technical Assistance Office to the Palestinians. Website. Available at: http://ec.europa.eu/delegations/westbank/ [Accessed 26 July 2014]

2. European Union. 2003. European Security Strategy [online]. Available at: http://www.consilium.europa.eu/uedocs/cmsUpload/78367.pdf [Accessed 26 July 2014] 


\section{Secururity}

3. European Union. 2008. Report on the implementation of the European Security Strategy [online]. Available at:

http://www.consilium.europa.eu/ueDocs/cms_Data/docs/pressdata/EN/reports/10 4630.pdf [Accessed 26 July 2014] 